Article

\title{
The Methodology Utilized in the Redaction of the Tripartite Structure of Sugyot from Tractate Eruvin in the Babylonian Talmud
}

\section{Uri Zur}

Moreshet Israel, Ariel University, Kiriat HaMada’a, Ariel 40700, Israel; uriz@ariel.ac.il; Tel.: +972-054-339-4717

Received: 3 June 2017; Accepted: 3 July 2017; Published: 13 July 2017

\begin{abstract}
This paper deals with the methodology utilized in the redaction of the tripartite structure of sugyot from Tractate Eruvin. The paper begins with a short review of the tripartite structure in various sugyot of the Babylonian Talmud. It presents the various methodologies utilized in the redaction of the tripartite structure of sugyot from Tractate Eruvin. The paper's significance is in its presentation of the various methods utilized in redaction of the tripartite structure, accompanied by select examples from different texts in Tractate Eruvin. These methodological methods are also evident in other sugyot and they constitute an important research foundation for examining their application in additional sugyot in the different tractates.
\end{abstract}

Keywords: Eruvin; methodology; redaction; tripartite structure; sugya

\section{The Tripartite Structure in Sugyot of the Babylonian Talmud}

The most common and cherished stylistic-formative design utilized in sugyot in general, including in Tractate Eruvin, is the tripartite structure (Friedman 1978; Zur 1999). ${ }^{1}$ An entire study focusing on presentation of the tripartite structure in the different texts of Tractate Eruvin as a whole has been devoted to this matter (Zur 2016).

The tripartite structure appears in many texts and in varied manners, and its main aspect is the formative-stylistic dimension, manifested in the content (for example, a phrase, give-and-take, etc.) or as an arrangement of three things together, for example three statements by a certain sage in one place in the text, sometimes despite the absence of any content-based connection between the statements (HaLevi 1970; Sirilio 1972; Weiss 1962, pp. 202-4), or three statements by different Amoraim. ${ }^{2}$

The tripartite structure is present in various texts as a form- and style-matching unit and as part of the redactors' considerations in redacting the content of the Talmudic text (Valler 1995; Valler 1999).

The study of different texts in Tractate Eruvin indicates that many texts have diverse modes of design, with one of the main variations being the tripartite structure.

The tripartite structure is considered a complete formative-stylistic structure, one with a beginning, middle, and end. ${ }^{3}$ At times, awareness and recognition of this stylistic form can solve many problems or various types of difficulties that arise in the Talmudic text. In other words, if the commentators had been clearly aware of the possibility that the sugya includes a formative-stylistic aspect and that a certain sugya may be shaped in a tripartite structure, then they would not have had difficulty understanding, for example, why three citations are brought in the name of the same amora despite

(Jacobs 1983, p. 138): "The use of this number as especially is widespread in the Rabbinic literature."

(Friedman, ibid., pp. 40-41).

(M. H. Pope 1962): "Next to the number Seven, the number most frequently used in connection with sacred matters is three. This number naturally suggests the idea of completeness-of beginning, middle, and end." 
the lack of a content association between the third citation and the two previous ones, for example in sugya $40 \mathrm{~b}-41 \mathrm{~b}$, as they would have been aware of the possibility of style-based repetition and would have had no difficulty with it. In fact, all the different examples in this paper suggest a method in which the tripartite structure of the text constitutes a form- and style-based solution for overcoming the difficulties caused by unnecessary repetitions in all the variations of those examples. Notably, the commentators who pondered problems or difficulties that arose in certain texts usually explained these as they were wont, by using casuistry and with no regard for the formative-stylistic design in the tripartite structure of the talmudic text. Nevertheless, it must be stressed that some of the commentators discerned the tripartite structure of the text and even alluded to it at times in their commentaries, or notice of the tripartite structure was implied "between the lines" of their exegesis.

Some of the commentators referred to the tripartite structure indirectly or in an implied manner in various texts (Zur 2016, pp. 71-74, 94-99, p. 140 n. 30, p. 187 n. 46; HaLivni 1982, p. 138, n. 1*). Their interpretations do not explain why the talmudic redactors acted thus, but it is clear that this was done for a certain purpose, and they seem to have realized that the redaction of the various texts stemmed from the wish to maintain a tripartite structure, although they do not say so expressly.

Some modern scholars also dwelt on the tripartite structure of various texts in several tractates of the Babylonian Talmud. There were those who expanded on the topic while others discussed it concisely, in passing.

The tripartite structure of sugyot in the Babylonian Talmud (Friedman 1997; Friedman 2010) is the topic of studies on the tenth chapter of Tractate Yevamot, and on the first and second chapters of Tractate Bava Metzi'a (Friedman 1997, p. 391, n. 6; Friedman 1978, pp. 40-43, 47). Other studies focus on sugyot in the first three chapters of Tractate Eruvin (Zur 1999, pp. 40, n. 6, 368, 392-93; Zur 2000; Zur 2013; Zur 2015) and on other chapters of the tractate (Zur 2016, pp. 23-366), as well as in other places. ${ }^{5}$

Some of the scholars who studied the sugyot of Tractate Eruvin paid very little attention (when at all) to the tripartite structure of some of the sugyot, and even this only indirectly, randomly, and unsystematically. They mentioned various phenomena related to the tripartite structure in texts or as a whole texts bearing the tripartite format in Tractate Eruvin (Zur 2016, pp. 54-62; Weiss 1929; Weiss 1962, p. 209; Friedman 1997). ${ }^{6}$

\section{The Methodology of Redaction of a Tripartite Structure}

The tripartite structure in sugyot of Tractate Eruvin appears conspicuously and clearly in forty sugyot and features a range of different stylistic forms, and in these forty sugyot the tripartite structure can be proven. Some sugyot have a visible tripartite structure, but this could not be proven.

Below, we shall select examples of different methodologies utilized in the redaction of the tripartite structure in various sugyot of Tractate Eruvin.

\subsection{Distinction and Separation (הפרדה וחלוקה)}

The methodology of distinction and separation in the sugyot is manifested in different ways. In one sugya ("Amar Abaye ...: Amat Sukkah"), ${ }^{7}$ the sugya's redactors had before them an array of difficulties and replies as a single sequence (or as one unit) in a certain topic ("Abaye stated in the name of R. Nahman: The cubit [applicable to the measurements] of sukkah and that applicable to an 'entrance' is one of five [handbreadths]. The cubit [applicable to the laws] of kil'ayim is one of six [handbreadths]")

\footnotetext{
For a critique of HaLivni's method, see (Newman 1983; Cohen 1998).

On the number three in various tractates of the Babylonian (and Jerusalemi) Talmud and in the various midrashim, see (Wünsche 1911; Melamed 1962; Nádor 1962, pp: 301-3, 313, 315; Jacobs 1983)

6 For a critique of Weiss' method in general, see (Brooks and Davis 1983; Cohen 1998).

7 Eruvin $3 b$.
} 
[here and henceforth from the Epstein ed.]. The methodology employed by the redactors was to distinguish between the difficulties and to separate them into three give-and-take relationships in order to establish a tripartite structure based on an identical style of negotiation ("1. In respect of what legal [restriction has it been ruled that] the cubit [applicable to the measurements] of an entrance is [only] one of five?..." 2. "In respect of what legal ... the cubit ... of a sukkah is one of five?..." 3. "In respect of what legal ... 'the cubit ... of kil'ayim is one of six'?...") (Zur 2016, pp. 28-29).

Another example is evident in three questions of Rabbah from R. Huna, joined together in one place in the sugya ("Amar Rabbah: Ki havenan bei R. Huna") in light of the identical name of the sage in the phrase ("Rabbah stated: When we were at R. Huna's we raised the following question ... "). Modern scholars too reached a conclusion concerning the methodology utilized by the redactors: "Statement A pertains to the framework mishna [the mishna that forms the setting of the issue]. Statement B is already to be considered [a transition] to another issue. But Statement C is from an entirely different issue, and it seems to have found its place here only by reason [in light] of the framework [of the phrase]: 'When we were ... he had no ruling on the subject. I appeared before Rab Judah' etc. And from this [we learn] that the three statements were supplied in a single instance." (Weiss 1962, p. 209). Namely, the redactors received these three questions as one unit, but they distinguished between them methodologically and separated them into three disparate units in order to establish a tripartite structure in light of the identical name of the sage and the recurring phrase mentioned above.

Such separation and distinction can be seen in a Tannaitic source as well. The redactors of the sugya ("Tanu Rabbanan: Sheloshah devarim") ${ }^{8}$ distinguished between the parts of the baraita methodologically and separated them into three parts. Next to each of the three parts of the baraita the redactors arranged a short give-and-take in a matching form of one identical difficulty and one short reply that illustrates only one example in each of the three instances of give-and-take, as a tripartite structure based on an adapted give-and-take. ${ }^{9}$

In another case, the redactors used the method of distinction and separation of three proofs brought together in order to establish a tripartite structure in the sugya ("Amar R. Mesharshiya: Litenaho lehanei klalei"). ${ }^{10}$ This method is evident in the following exegesis: "It makes more sense to say that he who wished to prove that the halakhic rules [mentioned above (46b)] cannot be accepted based on the three sources in which the ruling followed R. Simeon. And he brought all these difficulties [concerning those three sources in which the ruling followed R. Simeon] at once and in one instance and rejected them all using the one rejection ("Is it not possible that the rules are disregarded only where a ruling to the contrary had been stated, but that where no such ruling is stated the rules remain in force?"). However the redactors of the Talmud [who edited the sugya] arranged for us each proof [each of the three sources mentioned above in which the ruling followed R. Simeon] separately, with the same rejection [that is repeated as a rejection of each of the three sources] by its side, this seems clear to me."11

This alludes to the method utilized in redacting a tripartite structure in the text. To begin with, the redactors had before them the entire body of text (the three proofs, or to be precise three mishnayot, in which the ruling followed R. Simeon)-and they were said at once, and all rejected at once in one rejection.

But methodologically, the redactors distinguished between these three sources and separated them, arranging each of these three proofs as three separate difficulties, as though each difficulty had been presented separately to begin with, and added beside each of the three difficulties the same rejection, as though the rejection had been brought specifically for that difficulty.

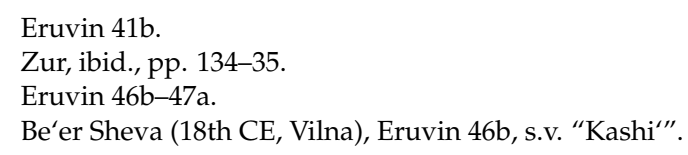


The interpretation of the commentator mention above does not explain why the redactors did this, but it may be said that they used this method in order to establish a tripartite structure.

\subsection{Refraining from Redaction of Potential Material (or Things) (פוטנציאלייםהימנעות מעריכת חומר או דברים)}

The methodology of refraining from redacting potential material in sugyot is manifested in various ways. When the redactors had before them other possibilities of redacting difficulties and replies that could be included in the sugya, sometimes and for various methodological considerations, for example establishment of a tripartite structure, they refrained from including them in the text.

This is also the opinion voiced by commentators concerning the redactors' refraining from inclusion of possible difficulties and replies in a certain sugya ("Amar Abaye ... : Amat Sukkah"), ${ }^{12}$ as one commentator stated: "The talmudic [redactors] saw no need to present all [the difficulties and the replies]"13). The commentator did not give the reason for this, but it may be posited to have derived from the consideration of establishing a tripartite structure. ${ }^{14}$

This methodology is evident in a give-and-take in another sugya ("Amar R. Hiyya: Shi'urin") $)^{15}$ as well. The redactors refrained from including in the give-and-take (on the topic of "[The law relating to] standards" 16 various controversies or other individual difficulties, for different reasons.

Some of the commentators think so too and according to them: "Whenever they [redactors] presented [this difficulty] in Tractate Sukkah [5b] and in Eruvin [4a] they brought all the words of R. Hanan."17

The words of the commentators imply an almost technical methodological approach by the redactors with regard to redaction of any give-and-take that repeats itself in other places in the Talmud. According to them, and from a methodological perspective, sometimes a give-and-take on a certain topic that recurs in another place in the Talmud, will include only the basic details of the give-and-take, for different reasons, for example the give-and-take on the words of R. Hanan, brought on its own from the parallel in Tractate Sukkah to Tractate Eruvin [4a-b] without the rest. This is because the give-and-take (from Tractate Sukkah) in Tractate Eruvin was only intended as part of establishing the tripartite structure, and the redactors refrained from expanding the give-and-take [in Eruvin] by bringing possible additions that appear in parallel sugyot. ${ }^{18}$

In another case, when a certain premise or possibility in a sugya ("Dekulei alma kassavrei mutar ... lehishtamesh") created an impasse ${ }^{19}$ the methodology utilized by the redactors was to try and present another improved and emended premise. ${ }^{20}$ For this reason, the text includes at times three premises one after the other.

But then again, although it would have been desirable (or possible) to add a fourth premise ${ }^{21}$ that would be better than the three previous ones, the methodology of the redactors was to refrain from adding it for different reasons, for example due to the consideration of establishing a tripartite structure. $^{22}$

In another example, two statements in the name of R. Jacob and R. Zerika and in the name of $\mathrm{R}$. Jacob b. Idi ruling in the name of R. Johanan appeared as two parts that comprise a tripartite structure

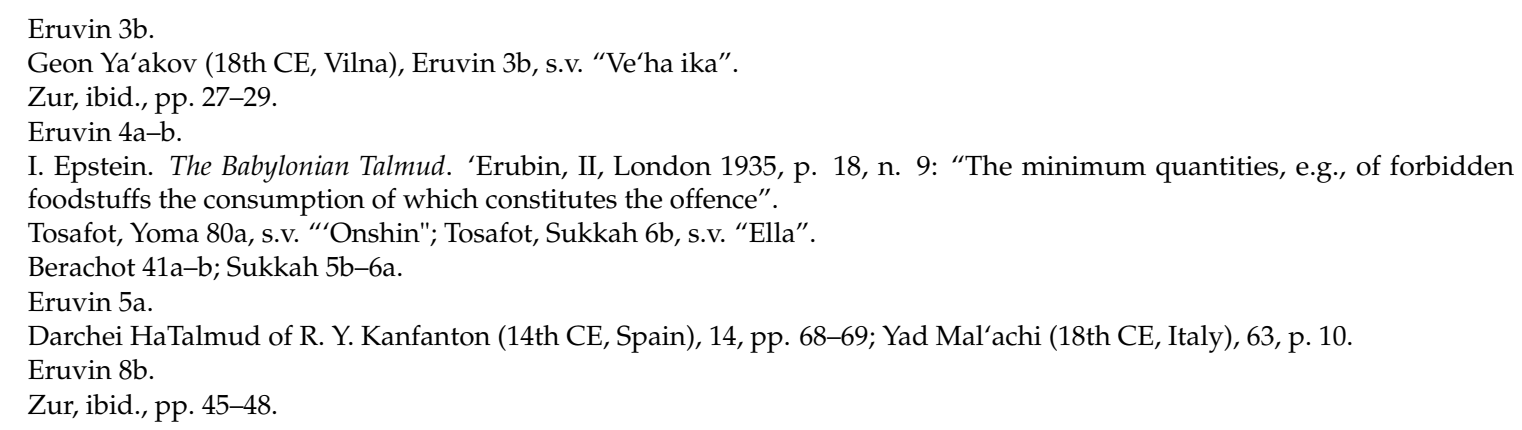


within the sugya ("R. Ya'akov veR. Zerika amru: Halachah"). ${ }^{23}$ The redactors methodologically avoided discussing each of these halakhic rules separately (although they could have done so) and did not pose difficulties between them or with regard to them ${ }^{24}$ in order to maintain the stylistic consistency of the tripartite structure, with the two parts having in common three different halakhic rules encompassed by each of the two statements. ${ }^{25}$

Thus also in the redaction of three stories on a certain topic ("A child whose warm water was spilled"), ${ }^{26}$ the redactors methodologically refrained from stating fundamental differences between them.

Therefore, in the absence of fundamental differences between these three stories, the first story, or the second and third, cannot be seen as redundant. This is because, methodologically, the joining of these three stories together in the text is intended to establish a tripartite structure within a common topic $^{27}$ ("A child whose warm water was spilled"). ${ }^{28}$

\subsection{Language and Style (לשון (לסגנון)}

The methodology utilized in matters of language and style took various forms; for example, the methodology of redacting a double phrase as two identical replies in the sugya ("Eiba'aya leho leHananya aliba devet Hillel") in the name of R. Mattenah in the name of Samuel ${ }^{29}$ is based on the consideration of establishing a tripartite structure with the same reply and the same phraseology: "... Samuel: It is not necessary to lock it [the door]"30 in all three replies with regard to a certain question ("The question was raised: According to Hanania's ruling in the name of Beth Hillel") in the text.

In another case it is possible to discern a linguistic addition. A certain source preserves another version that does not include a certain phrase in the sugya ("Gufa, amar R. Hisda: Tzurat ha'petach she'amru") (for example, in the words of R. Hananel, assuming that he preserves a version without the form "the shape of a doorway"), ${ }^{31}$ and it is possible that, to begin with, the form "the shape of a doorway" existed neither in the baraita nor in the two ${ }^{32}$ statements that appear in the sugya. Hence, this form may have been added to the printed version at some (later) stage. The methodology utilized in the redaction of this linguistic addition was intended to form a stylistic linguistic compatibility both within the baraita and in the two statements, which to begin with were not said together rather separately and the redactors arranged them here together ${ }^{33}$ in order to establish a tripartite structure based on the phrase "the shape of a doorway" (Weiss 1929; HaLivni 1982, p. 26, n. 12).

In another place, the methodology utilized in the redaction of three difficulties in a sugya ("Eitiveh, hatzer she'ha'rabim") ${ }^{34}$ stems from "literary grounds". ${ }^{35}$ In other words, the redactors arranged the three difficulties using the same formative style and the same phraseology ("A private domain in respect of the Sabbath and that of a public domain in respect of Levitical defilement ${ }^{36} \ldots$ whose view [is this]? If it be suggested [that it is that of] the Rabbis, it might be objected: If there,

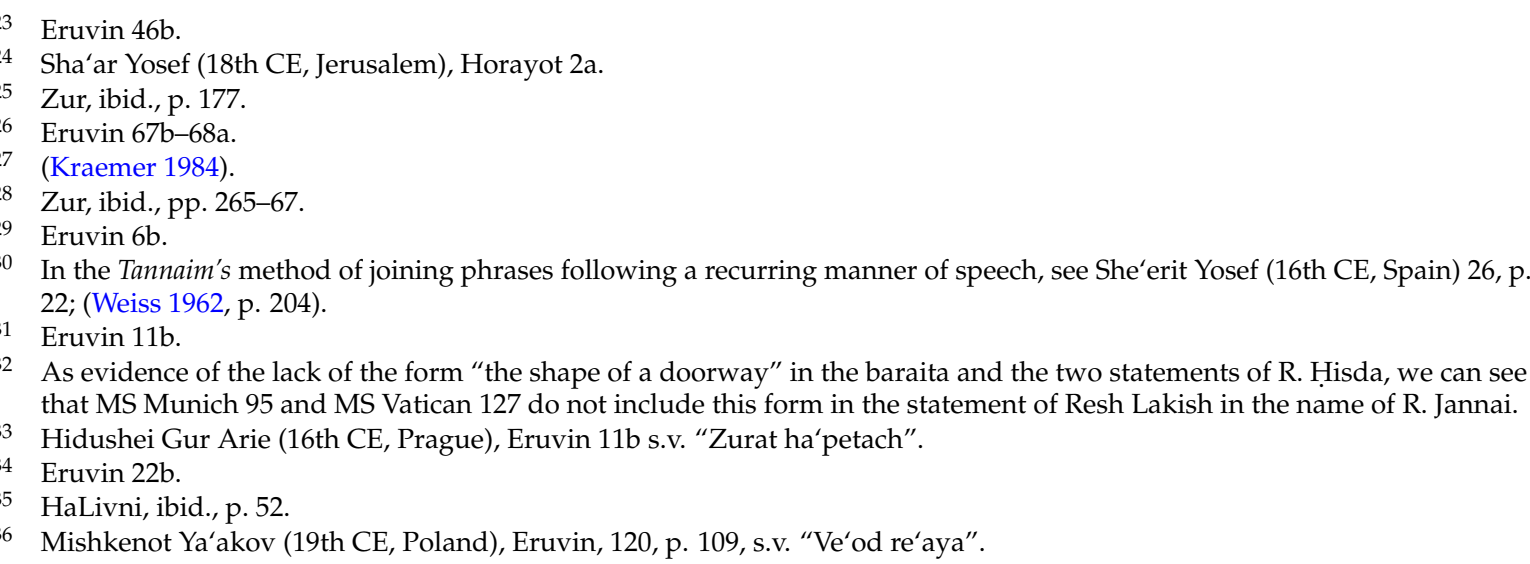


where the use [of the road] is easy, the Rabbis ruled that the public cannot come and impair the validity of the partition how much more would that be the case here where the use [of the paths] is not easy. Consequently [it must be, must it not, the view of] R. Judah?") in order to establish an identical formative-stylistic tripartite structure with the same phraseology based on these three difficulties.

Moreover, the cohesiveness of three proofs (according to R. Shesheth) in the sugya ("VeR. Shesheth amar echad zeh") $)^{37}$ is also methodologically manifested by the redactors in a formative-stylistic manner as a tripartite structure in the opening words: "Said R. Shesheth, do I drive this?"

One of the commentators noticed this phenomenon and alluded to it in his words, in the formative-stylistic impasse he noted in this regard: "It should be noted, that he [the redactor] should have said [and added] 'and Rav Sheshet said' [with the conjunctive vav] in the other "Do I drive this?" [three] phrases as well". ${ }^{38}$

This indicates that the two proofs in the text (the second and third or at least the third), accompanied by the phrase "Do I drive this?" of R. Shesheth, should have been preceded by the words "R. Shesheth again said" with a conjunctive vav as an addition to the first proof.

Accordingly, this commentator sees these three proofs as one cohesive grouping that aims to denote three proofs supporting the opinion of R. Shesheth.

Therefore, he undoubtedly noticed the methodology of these three proofs and he sees them as a tripartite structure (even if he did not state so explicitly) based on the three proofs supporting the opinion of R. Shesheth, as evident in the phrase: "R. Shesheth, do I drive this?" (Hyman 1964; Epstein 1957; Weiss 1962, p. 204 ${ }^{39}$ )

In another place, it is possible to discern that the methodology utilized in grouping three stories in a sugya ("Amahatah devei Rav ki havo mishta'aya") ${ }^{40}$ was aimed at establishing a tripartite structure based on the common phraseology of the three stories: "when indulging in enigmatic speech". This phrase was added by the redactors (Valler and Ratzabi 2007; Valler 2003) deliberately ${ }^{41}$ and it is important and meaningful, ${ }^{42}$ because it creates a common link between the three stories that open with the same phrase "When indulging in enigmatic speech", 43 and portrays them together as a tripartite structure.

Another example of the linguistic methodology is the common phrase "why were the words of Torah compared to ..." $" 44$ that appears in three different homilies with the aim of establishing a tripartite structure in the sugya ("Amar R. Hiyya b. Aba ... mai dechativ notzer te'enah").

Notably, although other homilies with the same phrase of "why were the words of Torah compared to ... " (Epstein 1957; Weiss 1962, p. 204) ${ }^{45}$ could have been added to the homilies in the same text, they were not added because methodologically they were not compatible with another phrase in the same three homilies: "So it is the words of the Torah; the more one studies them the more relish he finds in them" (with a difference phrase but with the same meaning as in the second homily). Therefore, since from a linguistic perspective the content of the potential homilies was not compatible with the homilies in the text, they were not added to the text because the methodology utilized by the redactors was to establish a tripartite structure based on a common phrase in three homilies.

On another topic, the methodology utilized in order to place a certain statement in a sugya ("Amar R. Eliezer mai dechativ ve'anakim legargerotecha") ${ }^{46}$ was used by the redactors as

\footnotetext{
37 Eruvin 32a.

38 Pnei Shlomo (16th CE, Hungary), Eruvin 32a, s.v "Amar R. Shesheth".

39 HaLevi (14th CE?, Alghero), Halichot Olam, 2:2, 108, p. 31; Sirilio (15th CE?, Spain), Kelalei Shmuel, 343, p. 127.

40 Eruvin 53b.

41 For another instance of three stories arranged deliberately, see (Jacobs 1961): "It is abundantly clear that these three stories, whatever their origin, have been placed together in this way in order to preserve the pattern of working up to a climax".

42 In contrast to Valler, Ratzabi, ibid.

43 See above, n. 30.

44 Eruvin $54 \mathrm{a}-\mathrm{b}$

45 HaLevi (14th CE?, Alghero), Halichot Olam, 2:2, 108, p. 31; Sirilio (15th CE?, Spain), Kelalei Shmuel, 343, p. 127.

46 Eruvin 54a.
} 
an opportunity to add two other subsequent statements, with the aim of establishing a tripartite structure in the text.

This interpretation necessarily derives from its unclear textual location (as the first in a series of homilies). This is because the first statement comes from a group of homilies on the topic of generating signs of traditions; however the content of the first statement is different and deals with another topic-promoting the study of Torah. This topic of the first statement differs from the content of the preceding homilies on generating signs of traditions. ${ }^{47}$

But the methodology utilized in arranging this statement as a first statement within the textual group, stems from the redactors' decision to nevertheless position it as the first statement ${ }^{48}$ (both due to its content as dealing indirectly with Torah-promoting the study of Torah, and mainly) in order to attach to it two other statements, although the content of these two statements (concerning the type of people in which Torah will not be found) differs from the content of the first statement.

Namely, despite the different content of the homilies, between the first statement and the second and third statements, all three statements have an identical basis, having in common the phrase: "It is not in heaven'" (Dt. 30:12), ${ }^{49}$ intended to establish a tripartite structure stemming from these three statements, which have in common their linguistic form.

In another matter, the opinion of a certain sage ("Rab ruled, requires no transfer of possession") was presented as one side of the first controversy (between Rab and Samuel) in a sugya ("Eitmar shitufei mevo' $\left.\mathrm{ot}^{\prime \prime}\right),{ }^{50}$ although ostensibly it should not have been presented, as Rab's opinion contradicts the words of the mishna (Hauptman 2000). ${ }^{51}$

But the redactors nonetheless presented his opinion, not only because of the rule "Rab is a Tanna and is privileged to differ" 52 (namely, that Rab has the status of "Tanna" and can or may object to the mishna), but rather also methodologically, from a formative-stylistic aspect, in order to maintain a linguistic balance between the various opinions presented ("Rab ruled, requires no transfer of possession and Samuel ruled: It does require transfer of possession") in the controversies between Rab and Samuel, both in the first part ("Shittuf of alleys") and in the second part ("'Erub of Sabbath limits") of the tripartite structure.

Thus, in another sugya as well ("Ba'ei R. Hamma: Shtei amot"), ${ }^{53}$ there are three enquiries that are not only redundant in the text, ${ }^{54}$ but also create difficulties. ${ }^{55}$

However, from a methodological perspective they were nonetheless arranged in the text, as the three of them together create a tripartite structure due to the common phrase ${ }^{56}$ "Is it permitted to move an object two cubits along a roof and two cubits along a ... ?-What an enquiry", in these three enquiries, as well as the particular content hierarchy that links them.

Finally, the joining of three baraitot in a sugya ("Veraminaho delet ha'nigreret") ${ }^{57}$ is carried out on the methodological grounds of forming a tripartite structure based on the phrase "whenever they are fastened and suspended" common to them all. In fact, the phrase "whenever they are fastened and suspended" ${ }^{\prime \prime 8}$ was added to the first baraita for reasons of stylistic uniformity. Thus, in the second baraita as well it is possible to say that the phrase "[when they] have a hinge" was added (Zur 2016,

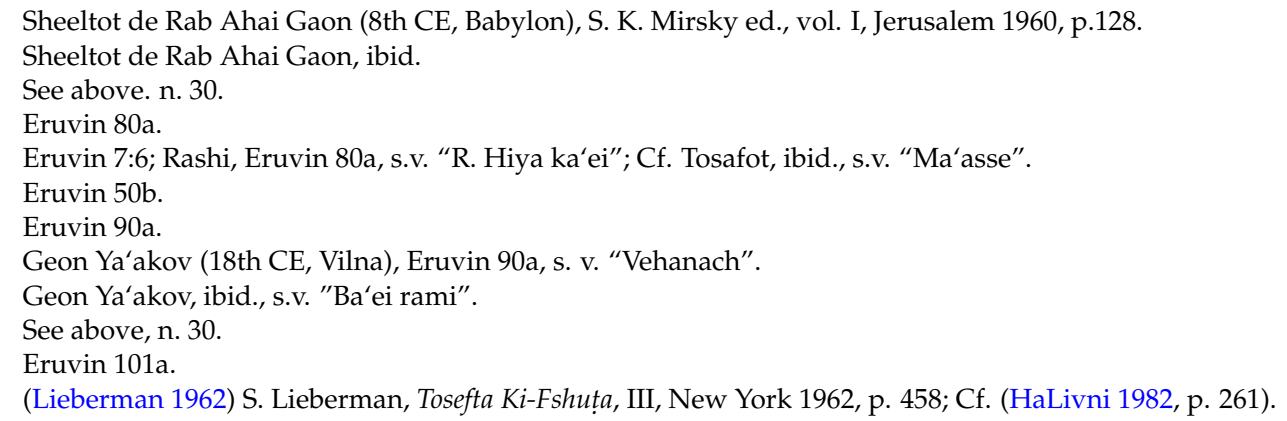


pp. 361-62 n. 90, 93) or replaced with ${ }^{59}$ the phrase "whenever they are fastened and suspended" for the same reason of stylistic uniformity in order to establish a three-baraita tripartite structure based on the one phrase "whenever they are fastened and suspended" in the three baraitot. ${ }^{60}$

\subsection{The Identity of the Sages' Names (זהות בשמות החכמים)}

This methodology, based on the identity of the sages' names, is also utilized in redaction of sugyot. For example, when the names of the sages in two homilies are identical, for instance in a sugya ("Amar leh R. Hisda leMari breh deR. Huna") ${ }^{61}$ in which the homilies appeared in the second and third part in the name of "R. Hisda stated, Mari b. Mar made the following exposition" and further to the words of the sage in the first part of the text ("R. Hisda stated"), then the redactors joined them together in the text methodologically in order to establish a tripartite structure.

Some of the commentators already discerned this phenomenon, and stressed: "Where Mari b. Mar is mentioned here in the entire matter [in the text], and for this reason they brought [the redactors brought both homilies in his name] in this sugya-because R. Hisda said them in the name of Mari [b. Mar]" ... "As if we do not say so, what is the role of these homilies within the text, i.e., why were they brought in the text". 62

Other commentators voiced similar suggestions: “The words of 'R. Hisda stated, Mari b. Mar made the following exposition' [were brought in the text] due to the identity [of the names] to the name of Mari son of R. Huna [mentioned] previously above, [for this reason] his homily was brought next to [or joined to] that of the previous speaker." ${ }^{\prime 63}$

"As if we do not say so, these statements [of the second and third part] do not belong here [in the text], rather only if as we wrote [these statements] were brought incidentally by reason of the [previous] statement above of 'Said R. Hisda to Mari son of R. Huna the son of R. Jeremiah b. Abba'" 64

From a methodological perspective, the redactors sought to establish a tripartite structure based on the identity of the sages' names: "R. Hisda" and "R. Hisda stated, Mari b. Mar made the following exposition". For this reason they did not bring another, fourth homily (assuming that they knew of such a homily resembling the other homilies that they knew and brought here in the text) in the name of "R. Hisda stated, Mari b. Mar made the following exposition" (Zur 2016, p. 73, n. 31). ${ }^{65}$

In another example, the redactors added a third statement to the sugya ("Amar R. Nahman amar Samuel: Yatza le' $\left.\mathrm{da}^{\prime} \mathrm{at}^{\prime \prime}\right)^{66}$ based on methodological considerations in light of the identity between the sages' names in the two previous statements. The commentators agree with this interpretation, as evident from their words: "They copied [redacted in the text] the controversy of R. Nahman in the name of Samuel and R. Huna for several reasons. One [the first] is because [the name of] R. Nahman in the name of Samuel [had already been mentioned] previously". ${ }^{67}$

The commentators clearly indicate that one of the reasons for joining the third statement to the two previous statements is that the name of that sage had been mentioned previously, in the second statement (and maybe they even mean the first statement), similar to the third statement that mentioned the name of the same sage "R. Nahman further stated in the name of Samuel".

In other words, methodologically, if the name of a certain sage was mentioned in the text previously, and there is another statement (or statements) in the name of that sage-the redactors will

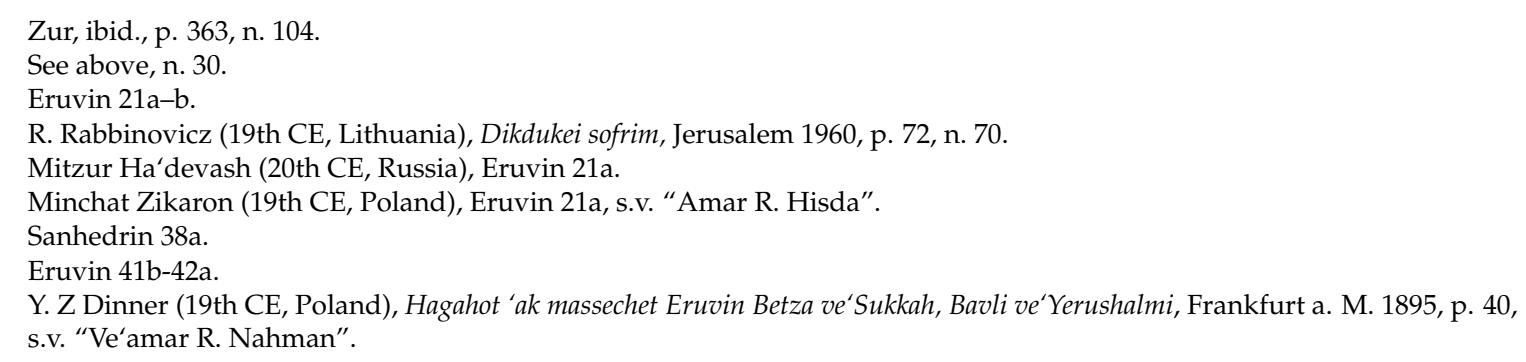


explore whether and how to join these statements together, for example in our case, joining the third statement to the first two stemmed from the redactors' decision to establish a tripartite structure based on the same name of the sage. ${ }^{68}$

In another place, the identical name of the sage in the tripartite structure is manifested in the phrase used to present a question. A certain question (which is in fact the first of the three questions of Rabbah from R. Huna) was brought in the sugya ("Amar Rabbah ki havenan bei R. Huna") ${ }^{69}$ due to its content-based association with the topic of the mishna. However the second question brought in the name of Rabbah from R. Huna, and the third question in the name of Rabbah from R. Huna as well, are redundant, because there is no content-based reason or any other evident reason for joining them to the text. The methodology utilized by the redactors in joining the two questions (the second and third) to the first question in one place was aimed at establishing a tripartite structure characterized by the identical name of the sage and the phrase used to present the question "Rabbah stated: When we were at R. Huna's we raised the following question".

This methodology, as a customary technique utilized in redactions, was also noted by the various commentators, for example: "[The redactors of] the Gemara [the Talmud] are accustomed [to utilize a methodology of] arranging together sayings [such as questions] by a single sage although they have no connection to each other", ${ }^{70}$ and also: "The arrangement [redaction] in which the [redactor of] the Gemara [Talmud] arranges [redacts] sayings [different matters, for instance questions] [said] by one amora, although they have no connection to each other ... and also the [methodological] technique utilized in the entire Gemara [the Talmud])" ${ }^{71}$

This methodology is also evident in words of the scholars: "The phrase 'And said R. so-and-so' in the Babylonian Talmud, i.e., that the person learning linked here, as he was wont, several different things only as a result of the name of the speaker" (Epstein 1957) (spacing in the original). Namely, the phrase "And said R. so-and-so" in the Babylonian Talmud, as presented in the sugya, takes this form because the person who learned it added other similar expressions in one location, despite their different contents, as a methodological technique, due to the identical name of the person who said them.

This methodology is also evident in the following words: "Three statements ... bearing a stamp of a separate uniform literary unit by reason of the name." ${ }^{\prime 2}$ In other words, three statements were brought in the sugya as a methodological technique only because they have a literary uniformity characterized by the identity of the speaking sage's name.

This methodology is also utilized with regard to the redaction of explanations brought in the name of the same sage. Two explanations brought in the name of a certain sage "Rabbah said", including his words cited a third time with the term "gufa" (meaning, turning to the main text stated above), were joined together in the sugya ("Amar Rabbah mai ta'ama deRav") ${ }^{73}$ as a methodology utilized by the redactors to establish a tripartite structure based on the identical name of the sage "Rabbah said".

The commentators noticed this phenomenon as well and alluded to it in their commentaries as follows: "I have seen again in the commentary of the R.N. [R. Nissim Gerondi, 14th CE, Spain] ... who explains this expression [' $\left.g u f a^{\prime}\right]$ and said 'for what we term [bring or cite in the sugya using the term ' $g u f a$ ' and even when the words brought do not say anything new [under the term ' $g u f a$ '], [they were nonetheless brought] because seeing as [the redactors] needed to bring these [two] statements by 'Raba' [brought previously], they brought this [third statement in the name of 'Raba'] once again as well". ${ }^{74}$

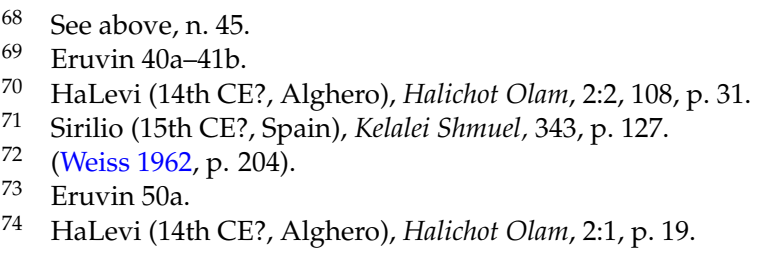


This was said about a sugya in Tractate Hullin, ${ }^{75}$ where one of "Raba's" statements was brought with the term " $g u f a$ " as part of a formative-stylistic structure of seven statements in the name of Raba. ${ }^{76}$

The methodical rule mentioned by the commentators above led to the following methodical rule cited subsequently: "And from this you shall learn—in any place that you shall find [the term] ' $g u f a$ ', if it does not bring something new [with regard to the issue brought under the term ' $g u f a$ '] then the [redactors'] intention is to group together all the laws [/or statements] said by [that sage who is] the speaker of the statement." 77

According to this commentator, it is possible to apply his interpretation to the sugya in Tractate Eruvin as well, and to say that the words of the sage ["Rabbah said"] brought for the third time in the sugya in Tractate Eruvin through the term "gufa", although they constitute no innovation (Albeck 1969; Zur 2016, p. 213, n. 10) (because they are in fact a verbal repetition of the words of "Rabbah said" mentioned previously in the second explanation), were nonetheless brought a third time-because these words (the third explanation) were preceded by two "Rabbah said" explanations. The redactors brought the words of "Rabbah said" again, a third time, through the term "gufa", as a way of establishing a tripartite structure based on the identical name of "Rabbah said".

In another place in a certain sugya ("De amar Samuel lo shanu") ${ }^{78}$ the expression "Samuel stated" (or "Samuel further stated") appears three times in three statements in the name of the Amora Samuel (in a different order in the second and third statement). ${ }^{79}$

The linguistic lengthiness of the words of "Samuel stated" (or "Samuel further stated") and the difficulties with regard to the three statements in the name of" Samuel stated", derive from the redactors' decision to nonetheless establish a tripartite structure with the phrase "This was learnt only in respect of a ... but ... acquire possession" 80 in the three statements in light of the identical name of "Samuel stated". ${ }^{81}$

The methodology utilized in the redaction of a tripartite structure in light of the identical sage's name is also used for a group of sages, as in the following example. A first statement brought in the name of "Elders of Pumbeditha" in a sugya ("Amar Rava hanei tartei milei") ${ }^{82}$ led methodologically to the joining of two additional statements in the name of "Elders of Pumbeditha" ${ }^{83}$ with the same phrase "The following ruling also was given by the elders of Pumbeditha", ${ }^{84}$ although the two last statements have no actual association with the first statement and no connection to matters of eruvin, all this as a methodology utilized by the redactors to establish a tripartite structure based on the identical names of the group of sages "Elders of Pumbeditha".

In fact, if the redactors had seen this specific text as a general place for gathering all the statements said in the name of "Elders of Pumbeditha", they would have had to mention other instances as well. ${ }^{85}$ But they did not do so because their methodology was aimed at redacting only three statements in a tripartite structure in light of the identical name of "Elders of Pumbeditha".

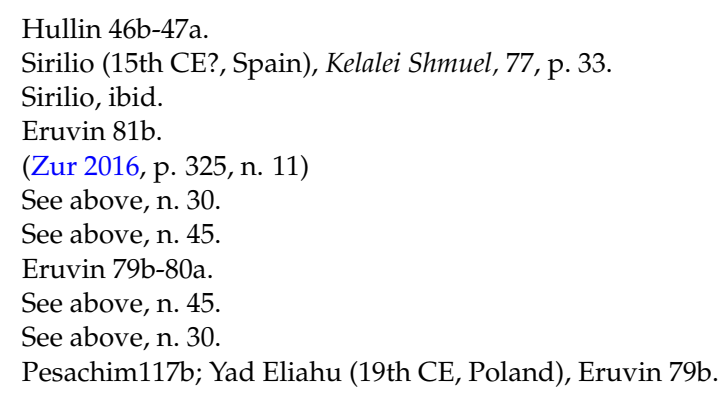




\subsection{Inessential Material (מאטריה שאינה מוכרחת)}

The methodology of including inessential material in the sugyot, resulting from the consideration of establishing a tripartite structure, can at times constitute a general explanation for its existence in some sugyot.

In this type of methodology it is possible to discern a certain sugya ("Ve'amai, hu bemakom echad") $)^{86}$ that encompasses two explanations. The first and second explanations were not accepted as responses to the opening question "But why? Is not this a case where he ${ }^{87}$ is in one place and his 'erub is in another?" due to the difficulties they entailed and, assumedly, they were inessential for the text and the redactors had no reason to bring them (or leave them) in the text. But they remained nonetheless and joined the third explanation that was accepted as a response to the opening question.

All this, because the methodology utilized by the redactors in adding the two explanations that were not accepted as responses, to the third explanation that was accepted, was to establish a tripartite structure based on these three explanations since "the approach of the Talmuds-[the Babylonian Talmud] is different [than that of the Yerushalmi Talmud]." ${ }^{88}$

Similarly, in another place, one of the examples (the third example) given on the issue of "a holding" (related to the matter of "an object that may be handled on the Sabbath the tenant imposes restrictions") in a sugya ("Hechei damei tefissat yard") ${ }^{89}$ is a general example that in fact also encompasses the two preceding individual examples of "a holding". Therefore, the two first examples are inessential in the text and the two individual examples preceding the third general example were not necessary, ${ }^{90}$ as the redactors could have made do with the one general, third example, as it alone is cited in a parallel sugya in another place: "What is one to understand by a holding? [An] object that may not be handled on the Sabbath the tenant imposes no restrictions". ${ }^{91}$ But from a methodological perspective, the two previous individual examples nevertheless remained in the text, although not essential, because the redactors did not make do with the one general example as they wished to establish a tripartite structure based on three examples of "a holding".

Similarly, three controversies between Rab and Samuel on various topics were brought in a sugya ("Gagin hashavin leR. Meir"), ${ }^{92}$ although they are not essential for the text due to the general difficulties involved in each. In the first controversy, there are doubts and uncertainty regarding Rab and Samuel's halakhic rulings on the topic under discussion. ${ }^{93}$ The second controversy is unnecessary or fictitious (because Samuel concedes that the halakha is in agreement with that of $\mathrm{Rab}^{94}$ and he retracts his words, ${ }^{95}$ and thus there is in fact no controversy between Rab and Samuel). Concerning the third controversy, its place does not suit the topic discussed in the text ${ }^{96}$ (and according to the words of " $\mathrm{R}$. Aha son of Raba" in the sugya, here too Samuel said that the halakha follows Rab and therefore there is in fact no third controversy between Rab and Samuel).

Nonetheless, although these three controversies are not essential, they were brought in the text methodologically in order to establish a tripartite structure based on Rab and Samuel's consistent halakhic approach: "Rab ruled: "It is permissible to move objects about throughout its area and Samuel ruled: Objects may be moved only within four cubits".

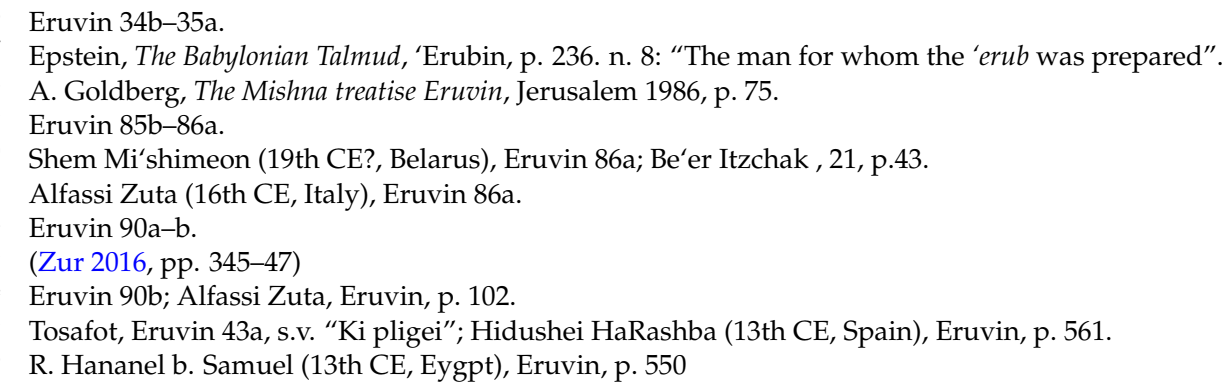




\subsection{Unique Redaction (עריכה ייחודית)}

This methodology is interesting and pertains to the special phenomena that emerge in the sugyot in which it is evident.

It is possible to discern a unique redaction in a certain sugya ("Amar Rabbah ki havenan bei R. Huna") ${ }^{97}$ where three questions in the name of Rabbah from R. Huna ("Rabbah stated: When we were at R. Huna's we raised the following question") conclude with a double ending on the same issue at the end of each of the three instances of give-and-take. The double ending in the first question is: "R. Hisda replied: [The mention of] one 'memorial' suffices for both. So also ruled Rabbah: [The mention of] one 'memorial' is sufficient for both". 98

The double ending in the second question is: "And the law is that the benediction on the season is to be recited both on the New Year festival and the Day of Atonement. And the law, furthermore, is that the benediction on the season may be said even in the street". ${ }^{99}$

The double ending in the third question is: "In view of Mar Zutra's exposition in the name of R. Huna that the halachah is that one fasting [on Sabbath eve] must complete the fast ... Mar Zutra made the following exposition in the name of R. Huna: The halachah is [that those] fasting [on a Sabbath eve] must complete the fast". 100

The methodology utilized by the redactors in designing the double ending is unique and stems from considerations of formative-stylistic uniformity aimed at establishing a tripartite structure based on these three questions.

In another place, the redactors of the sugya ("R. Ya'akov veR. Zerika amru: Halachah") 101 presented three statements that each encompass three halakhic rules (aside from the third statement, in which the third rule is missing, and although its lack was presented as a difficulty in the sugya it may have originally existed) in a tripartite structure and in a "three of three" form. ${ }^{102}$

From a methodological perspective, the redactors established a tripartite structure with the unique "three of three" form, meaning that each of the three statements includes three halakhic rules (with the exception of one rule in the third statement, as stated).

In another sugya ("Amar Rabbah ... : Kotel she'bein shtei hatzerot") 103 the redaction of three statements in the name of "R. Nahman citing Rabbah b. Abbuha" (or "R. Nahman further stated in the name of Rabbah b. Abbuha") in one place in the text constituted a unique methodology manifested in the establishment of a second tripartite structure immediately following the first tripartite structure in the same place. The consecutive first and second tripartite structures are intended to maintain the content sequence of the first tripartite structure. This although the first tripartite structure includes a certain statement in the name of an Amora from a later period (Abaye) than the sage's name ("R. Nahman further stated in the name of Rabbah b. Abbuha") that appears in the second tripartite structure that preceded Abaye chronologically. ${ }^{104}$

The unique methodology utilized by the redactors in this case was the priority given to establishing a second tripartite structure in the name of "R. Nahman further stated in the name of Rabbah b. Abbuha" and maintaining a continuity and consistency in the identity of the more ancient sage's name within the second tripartite structure, over maintaining the chronological order, manifested in bringing the statement of Abaye before that of the older sage ("R. Nahman further stated in the name of Rabbah b. Abbuha") - even if this created chronological disorder.

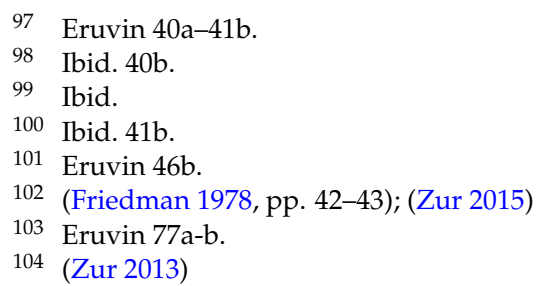


In other words, the redactors gave preference to the redaction of a second tripartite structure based on the name of a sage from an earlier period, although his words are arranged in the text after the statement of a later sage, over maintaining the chronological order-of arranging statements in the name of Amoraim by their chronological period (as stated, bringing the words of the later Abaye before the words of "R. Nahman further stated in the name of Rabbah b. Abbuha" who preceded Abaye in time).

As a consequence, the second tripartite structure ("Ve'amar R. Nahman: Sulam sheshlivotav porchot $\left.^{\prime \prime}\right)^{105}$ comes in addition and after the first tripartite structure that appears previously ${ }^{106}$ in the same text, with the unique methodology utilized by the redactors being the establishment of a double tripartite structure or one with a "three after three" form.

In another matter that deals with a comparison between a give-and-take in a sugya ("Amar R. Yochanan: Halon 'Agol")from Tractate Eruvin ${ }^{107}$ and a similar give-and-take from Tractate Sukkah, ${ }^{108}$ it appears that three difficulties in the give-and-take in Tractate Eruvin are a later addition brought from Tractate Sukkah (Aminoah 1988).

The unique methodology utilized in transferring these three difficulties from Tractate Sukkah to Tractate Eruvin is aimed at identifying a tripartite structure in the give-and-take that notes those "manners of calculation". ${ }^{109}$ This is in regard to the statement of R. Johanan in Eruvin by later redactors who transferred those "manners of calculation" from the give-and-take concerning "Sukkah [round shape] like a furnace" from Tractate Sukkah to Tractate Eruvin and "in a talmudic style of give-and-take", 110 in order to establish a tripartite structure based on these three difficulties.

Another sugya ("Rabina sar sakina bebavel") $)^{111}$ portrays the special methodological phenomenon of chaining between three stories (Zur 2016). The chaining is manifested in different features that link one story to the other or the similarity between these features in the first and second story (for example, the name of Rabina and checking the knife) and in the second and third story (random arrival in a certain place- -"once visited", checking the knife, and use of the phrase "Raba said: A young scholar may examine his own knife") through repetition (Rivlin 1978) of some of these features or the existence of the same features in the three stories. This unique chaining methodology unites the three stories as having a formative-stylistic connection and together they form a tripartite structure.

A final example that can be noted is the redaction of three rulings ("halachah" or "custom" or "the public act") ${ }^{112}$ that are parallel (Aminoah 1986) (or have a level of validity graded from the most strict-"halachah" to the most lenient- "the public act"), ${ }^{113}$ brought in the sugya ("Amar R. Yehudah amar Samuel: Halachah keR. Eliezer b. Ya'akov") as a unique methodology utilized for the establishment of a tripartite structure aimed at indicating that in each case (whether "halachah" or "custom" or "the public act") the ruling must follow the opinion of the sage mentioned through all these three terms, in the sugya discussed here where the ruling followed R. Eliezer b. Jacob who contradicts R. Meir.

The unique methodology utilized by the redactors was the use of a technique that in this case was intended to prevent the possibility that the halakhic ruling would follow the other sage- $\mathrm{R}$. Meir, as could have happened if the redactors had not used this unique methodology-because R. Meir is a sage ranked higher than the sage with whom the redactors sided halakhically-R. Eliezer b. Jacob,

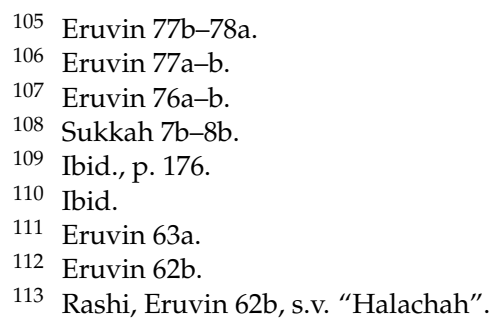


and the redactors used this unique methodology to prevent the possibility that halakha would follow the more senior sage- $\mathrm{R}$. Meir (Zur 2007).

Notably, in this sugya, the combination of the three terms ("halachah" or "custom" or "the public act") indeed influenced the adjudicators (Poskim) to rule following the opinion of R. Eliezer b. Jacob. But in two other sugyot ${ }^{114}$ this technique was not effective for different reasons. ${ }^{115}$

\section{Conclusions}

Tractate Eruvin includes forty sugyot that utilize a proven tripartite structure, while other sugyot in the tractate have a visible tripartite structure that cannot be proven. In other words, the tripartite structure in the latter sugyot is externally evident, for instance in the following example from Eruvin 14a-b: 1. "R. Hiyya taught: The sea that Solomon made... but consider: How much is the ritual bath"; 2. "The sea that Solomon made ... but consider: By how much does a square exceed that of a circle"; 3. "Rami b. Ezekiel learned that the sea that Solomon made ... now how much is a bath". The words used in the sugya emphasize the recurring similarities, but methodically this format finds no support in different versions, in the commentaries or in scholarly research.

Research on the tripartite structure in Tractate Eruvin is not unique, and this tractate was chosen without specific concern for the occurrence of the tripartite structure specifically there as opposed to other tractates - it was simply selected as a choice of what to analyze. No similar research has been systematically carried out in entire tractates, with the exception of Tractate Eruvin, and only selected chapters have been subjected to such inquiries. In this respect, research of the tripartite structure could focus on other tractates as well. This would make it possible to examine the prevalence of the tripartite structure in other tractates in comparison to Tractate Eruvin and to check whether the phenomenon of the tripartite structure in Tractate Eruvin has different features than in other tractates. In this paper, we presented six methodological routes to redact the tripartite structure in sugyot from Tractate Eruvin in the Babylonian Talmud.

The first part deals with the methodology of distinction and separation, and it includes various examples of this method with regard to difficulties and replies, statements or problems, proofs and tannaitic sources.

The second part deals with the methodology of avoiding redaction of potential material that could have been included in the sugyot but for which the redactors refrained from including it for various reasons. This method is demonstrated by refraining from including in the sugya difficulties and replies, controversies, various additions, premises or possibilities, discussions of halakhic rules, and noting significant differences.

The third part deals with the methodology of language and style. In this method, we offered various examples pertaining to linguistic issues, such as linguistic glosses, identical form and language, formative-stylistic design of the language, identical or shared phrases, and linguistic balance.

The fourth part deals with the methodology of sages' identical names. In this method, we presented various examples that refer to the identical name of the sage and one example that refers to the identical name of a group of sages.

The fifth part deals with inessential material in the sugyot. We demonstrated this method by presenting examples that are not essential as well as possibilities and controversies that are not essential.

The sixth part deals with the methodology of the unique redaction in sugyot. This method is demonstrated by a double ending, the "three of three" style, a double or "three after three" tripartite structure, transferring the same "manners of calculation" from a sugya in Tractate Sukkah to a sugya in Tractate Eruvin, the chaining of components that link three stories, and the redaction of three

\footnotetext{
114 Eruvin 72a; Ta'anith 26b.

115 Zur, ibid.
} 
parallel rulings or rulings that have a graded significance, in order to ensure that the ruling follows a certain sage.

Notably, other methodological techniques are also used in the redaction of sugyot in Tractate Eruvin, as well as various examples that illustrate these techniques. There are also varied phenomena in the sugyot of Tractate Eruvin that should be explored and studied.

\section{References}

Albeck, Chanoch. 1969. Introduction to the Talmud, Babli and Yerushalmi. Tel Aviv: Devîr, p. 656.

Aminoah, Noah. 1986. The Redaction of the Tractate Betza Rosh-HaShana and Ta'anith in the Babylonian Talmud. Tel Aviv: Tel Aviv University, p. 309.

Aminoah, Noah. 1988. The Redaction of the Tractate Sukkah and Moed-Katan in the Babylonian Talmud. Tel Aviv: Tel Aviv University, pp. 175-76.

Brooks, Roger, and Joseph M. Davis. 1983. Abraham Weiss as Exegete and Text Critic, The Case of b. Berakot 35a. Semeia 27: 105-16.

Cohen, Aryeh. 1998. Rereading Talmud: Gender, Law and the Poetics of Sugyot. Atlanta: Scholars Press, Brown Judaic Studies, pp. 25-33.

Epstein, Jacob Nachum. 1957. Introduction to Tannaitic Literature. Tel Aviv: Magnes, Devir, p. 302.

Friedman, Shamma. 1978. A Critical Study of Yevamot X with a Methodological Introduction. New York: The Jewish Theological Seminary of America.

Friedman, Shamma. 1997. Some structural patterns of Talmudic sugiot. Proceedings of the Sixth World Congress of Jewish Studies 3: 389-402.

Friedman, Shamma. 2010. Talmudic Studies, Investigation the Sugya, Variant Readings and Aggada. New York: The Jewish Theological Seminary of America, p. 10.

HaLevi, Yeshu'a. 1970. Halichot Olam, 3rd ed. Jerusalem: Shilo Press, p. 31.

HaLivni, David. 1982. Sources and Traditions: A Source Critical Commentary on the Talmud Tractates Erubin and Pesahim. New York: The Jewish Theological Seminary of America.

Hauptman, J. 2000. Nashim be'massechet Eruvin-Mi'telut hevratit le'atzmaut hukit. Mada'ei Ha'yahadut 40: 152. Hyman, Aaron. 1964. Toledot Tannaim ve'Amoraim. Jerusalem: Kirya Ne'emanah, vol. III, p. 1232.

Jacobs, Louis. 1961. Studies in Talmudic Logic and Methodology. London: Vallentine Mitchell, p. 67.

Jacobs, L. 1983. The Numbered Sequence as a Literary Device in the Talmudic Babylonian. In Hebrew Annual Review. Edited by Ahroni. Colombus Reuben: Division of Hebrew Language and Literature, vol. VII, pp. 138-42.

Kraemer, David Charles. 1984. Stylistic Characteristic of Amoraic Literature. Ph.D. Dissertation, The Jewish Theological Seminary of America, New York, NY, USA; p. 308.

Lieberman, S. 1962. Tosefta Ki-Fshuț. New York: The Jewish Theological Seminary of America New York, vol. III. Melamed, Ezra Zion. 1962. Nossach mispar u-mishkal be-massechet Avot. Sinai 50: 157-61.

Nádor, G. 1962. Some Numerical Categories in Ancient Rabbinical Literature: The Numbers Ten, Seven and Four. Acta Orientalia (Budapest). 14: 301-15.

Newman, L. 1983. The Work of David Weiss Halivni, A Source-Critical Commentary to b. Yebamot 87b. Semeia 27: 93-101.

M. H. Pope. 1962. Number, Numbering, Numbers. In The Interpreter's Dictionary of the Bible. Edited by George Arthur Buttrick. New York: Abingdon Press, vol. 3, p. 564.

Rivlin, Asher Aliezer. 1978. Munachon Le'sifrut. Tel Aviv: Ha'kibbutz Ha'Artzi, p. 64.

Sirilio, S. 1972. Kelalei Shmuel, Simcha Bunem David Soefer edition. Jerusalem: Divrei Sofrim, p. 127.

Valler, S. 1995. The Number Fourteen as a Literary Device in the Babylonian Talmud. Journal for the Study of Judaism 26: 169-84. [CrossRef]

Valler, S. 1999. Women and Womanhood in the Talmud. Atlanta: Scholars Press.

Valler, S. 2003. Women's talk-men's talk Babylonian Talmud Erubin 53a-54a. Revue des Études Juives 162: 421-45. [CrossRef]

Valler, S., and S. Ratzabi. 2007. Sichot Hullin ba'Talmud ha'Bavli. Tel Aviv: 'Am ‘Oved, p. 125.

Weiss, A. 1929. Le'korot Hithavut Ha'bavli. Jerusalem: Makor, p. 56, n. 5. 
Weiss, A. 1962. Studies in the Literature of the Amoraim. New York: Shulzinger Bros. Linotyping \&Publishing Co, pp. 202-4.

Wünsche, A. 1911. Die Zahlensprüche in Talmud und Midrasch. Zeitschrift der Deutschen Morgenländischen Gesellschaft 65: 66-100.

Zur, Uri. 1999. Orr Israel, Sugyot in Tractate Eruvin. Lod: The Habermann Institute for Literary Research.

Zur, Uri. 2000. 'Al ha'mivneh ha'meshulash be'sugyot ha'bavli. Te'udah 16-17: 255-73.

Zur, Uri. 2007. Hatzeruf 'Halacha', Minhag', 'Nahagu Ha'am' kederech le'kvi'at Halach. Sha'anan 12: 83-110.

Zur, Uri. 2013. Mivneh meshulash kaful be’sugya achat be’bavli ‘eruvin (77a-78a). Sha'anan 19: 77-88.

Zur, Uri. 2015. 'Eitzuv kelalei halachah be'mivneh meshulash ba'Talmud ha'bavli. Netu'eim 19: 122-30.

Zur, Uri. 2016. The Tripartite Structure of the Sugyot: Studies in Tractate Eruvin of the Babylonaian Talmud. New York: Ariel University Press, Ariel, Israel \& David Publishing Company.

Zur, Uri. 2016. Chaining as a Structuring Means of the Sugya in the Bavli. Revue des Études Juives 175: 415-23.

2017 by the author. Licensee MDPI, Basel, Switzerland. This article is an open access article distributed under the terms and conditions of the Creative Commons Attribution (CC BY) license (http:// creativecommons.org/licenses/by/4.0/). 